\title{
Immobilization of bacterial association in alginate beads for bioremediation of oil-contaminated lands
}

\author{
Žanete Zommere, Vizma Nikolajeva* \\ Department of Microbiology and Biotechnology, Faculty of Biology, University of Latvia, Jelgavas 1, Riga LV-1004, Latvia \\ ${ }^{\star}$ Corresponding author, E-mail: vizma.nikolajeva@lu.lv
}

\begin{abstract}
Entrapment in alginate gel is a widely used approach for immobilization of microorganisms to improve their viability. A natural bacterial association consisting of seven strains isolated from acid tar-contaminated soil was used for immobilization in alginate gel. The aim of this study was to identify conditions for entrapment of a bacterial association and to determine conditions for its prolonged storage. The association was successfully immobilized in $1.5 \%$ alginate beads that were $2 \mathrm{~mm}$ in diameter. All tested treatments, with or without $5 \%$ clay, with or without $10 \%$ glycerol, and with or without incubation of prepared beads in nutrient medium or $0.2 \mathrm{M}$ solution of $\mathrm{CaCl}_{2}$, showed good results in terms of survival of bacteria immediately after entrapment in gel and during at least six months storage of beads at temperature of 4 and $20^{\circ} \mathrm{C}$. The number of bacterial colony-forming units increased by 1.1 to 1.3 log g ${ }^{-1}$ in clay-containing beads during the experiment, regardless of storage temperature but it remained at baseline levels in other treatments. Further studies are necessary to evaluate bioremediation activities of the immobilized association in laboratory and field conditions.
\end{abstract}

Key words: alginate, bacteria, bacterial association, gel entrapment, immobilization.

Abbreviations: CFU, colony-forming units; MHB, Mueller Hinton Broth.

\section{Introduction}

Environmental bioremediation is a profitable and promising technology, which can lead to complete mineralization of organic pollution. Bioaugmentation (introduction of selected microorganisms to supplement indigenous populations) is one of the bioremediation approaches (Hassanshahian et al. 2014). Successful bioaugmentation can be expected by enrichment cultures obtained from previously contaminated sites. However, problems arising from competition between introduced and indigenous microorganisms and between mixed microbial strains in the cultivated consortium cannot be precluded (reviewed in McCarty, Criddle 2012). Thus, Hassanshahian et al. (2014) showed reduced biodegradation capability of the consortium (Alcanivorax borkumensis and Thalassolituus oleivorans), suggesting unfavourable interaction. Success of bioaugmentation also largely depends on the ability of inoculants to survive in the usually harsh conditions (toxic or inhibitory substances, unsuitable $\mathrm{pH}$, osmotic stress etc.) of polluted environments. One of the biggest problems is survival of inocula after administration (Bento et al. 2005). Promotion of biodegradation may be achieved by use of immobilized cells (reviewed in Mrozik, PiotrowskaSeget 2010). The carrier provides a protective niche to microorganisms and ensures viability over a prolonged period of release. Several organic carriers have been tested for soil bioremediation, including chitin, chitosan, gellan gum, polyvinyl alcohol etc. (reviewed in Lebeau 2011) as well as an organomineral complex prepared from humic acids bound on zeolite (Dercova et al. 2007).

Many biodegrading microorganisms belong to the genera Acinetobacter (Luckarift et al. 2011), Alcanivorax (Hassanshahian et al. 2014), Bacillus (Gupta et al. 2000), Burkholderia (Mohanty, Mukherji 2008), Marinobacter, Pseudomonas (Abed et al. 2014), Rhodococcus (Kundu et al. 2016), Sphingomonas (Matsumura et al. 2015) and Thalassolituus (Crisafi et al. 2016). Szulc et al. (2014) selected a consortium consisting of Aeromonas hydrophila, Alcaligenes xylosoxidans, Gordonia sp., Pseudomonas fluorescens, Pseudomonas putida, Rhodococcus equi, Stenotrophomonas maltophilia and Xanthomonas sp. for diesel-oil contaminated soil bioremediation. Crisafi et al. (2016) investigated a hydrocarbonoclastic consortium consisting of Alcanivorax borkumensis, Alcanivorax dieselolei, Marinobacter hydrocarbonoclasticus, Cycloclasticus sp. 78-ME and Thalassolituus oleivorans. A consortium of Acinetobacter, Pseudomonas, Microbacterium and Ralstonia species was found to have polycyclic aromatic hydrocarbons-degradation capability (Simarro et al. 2013).

Immobilized cell systems are classified into four categories based on the physical mechanism of the localisation and nature of the support mechanisms: adsorption, aggregation, confinement and entrapment (reviewed in Karel et al. 1985; Cassidy et al. 1996). Gel entrapment with natural polymers, such as agar, alginate, 
carrageenan and cellulose and its derivatives, collagen and gelatin, is a mild technique and takes place under ambient conditions when damage to living cells can be minimized. Disadvantages are the poor mechanical strength and the limited longevity of the gel structure. Algal polysaccharides: alginate, carrageenan and agar are the most widely used (reviewed in Willaert, Baron 1996). Alginate is a binary linear heteropolymer containing 1,4-linked $\beta$-Dmannuronic and $\alpha$-L-guluronic acid residues in varying proportion and sequence and are characterized by a selective binding of calcium ions in solution (Smidsrød 1974). The droplets form a gel instantaneously and entrap cells in a three-dimensional porous matrix of cross-linked alginate. The most common forms are small beads about 1 to $5 \mathrm{~mm}$ in diameter. Entrapment of microbial cells within beads of calcium alginate has become one of the most widely used immobilization methods. The major disadvantage of alginate beads is its sensitivity to chelating agents such as EDTA, citrate, lactate, phosphate, or antigelling cations such as sodium and magnesium. They can be used to dissolve gel (Mørch et al. 2006). Alginate, being a natural polymer, is biodegradable and therefore environmentally friendly. Several genera of bacteria are reported to contain alginate-lyases producing and alginate degrading strains, for example, Gracilibacillus (Tang et al. 2009), marine Streptomyces sp. (Kim et al. 2009), and the production of an extracellular alginate-degrading enzyme is one of the characteristics of genus Vibrio (Kitamikado et al. 1990).

Alginate is known as a biomaterial with numerous applications in biomedicine due to its biocompatibility and low toxicity (reviewed in Lee, Mooney 2012). Alginate-clay composites are suitable for environmental remediation as sorbents of heavy metals (Shawky 2011) and persistent organic pollutants (Barreca et al.2014). Alginate is also used as an inoculant carrier for plant growth promoting bacteria (Bashan 1986; Trivedi et al. 2005), for biocontrol agents (Fravel et al. 1985; Pradeep, Subbaiah 2016) and for bacteria with biodegradation ability ( $\mathrm{Li}$ et al. 2005). Alginateimmobilized bacteria have shown an higher tolerance to toxic compounds (Kim et al. 2006) and better xenobiotic degradation rates (Li et al. 2005; Pradeep, Subbaiah 2016) than non-immobilized cells. Formulations containing inorganic and organic materials such as kaolin clay or wheat bran (Lewis, Papavizas 1985), montmorillonite clay (Weir et al. 1995), glycerol (Zohar-Perez et al. 2002) or skim milk (Trivedi et al. 2005) have demonstrated increased viability during storage.

The aim of this study was to identify conditions for entrapment of a new bacterial association suitable for bioremediation of oil-contaminated lands in alginate beads and to determine conditions for its prolonged storage. Effect of clay and glycerol in bead formulations and effect of incubation medium were evaluated. Survival of bacteria was determined during six months of storage of beads at temperature of 4 and $20^{\circ} \mathrm{C}$.

\section{Materials and methods}

\section{Microorganisms}

A natural microbial association containing seven bacterial strains was used. Components of the association were Acinetobacter sp., Bacillus circulans, Bacillus licheniformis, Brevibacillus brevis, Burkholderia cepacia, Leifsonia aquatica and Sphingomonas paucimobilis. This association was isolated by Dr. biol. Livija Vulfa about 20 years ago from soil contaminated with acid-tar in the neighbourhood of Inčukalns (Latvia) and the association is maintained in the Microbial Strain Collection of Latvia, University of Latvia, accession number MSCL 311.

\section{Immobilization and storage of bacteria}

Immobilization was carried out using a modification of the method described by Bashan (1986). The bacterial association was cultivated on Plate Count Agar (Bio-Rad, France) for 7 days at $20^{\circ} \mathrm{C}$. Encapsulation was performed using a sterile $3 \%$ solution of sodium alginate (Duchefa Biochemie, Netherlands) and $0.2 \mathrm{M} \mathrm{CaCl}_{2}$ (Ing. Pert Švec - PENTA s.r.o., Czech Republic). Treatments with addition of clay powder (Ceplis Ltd., Latvia) $5 \mathrm{~g}$ per $100 \mathrm{~mL}$ of $3 \%$ alginate and analytical glycerol (P.P.H. „Stanlab”, Poland) $10 \mathrm{~g}$ per $100 \mathrm{~mL}$ of $3 \%$ alginate also were prepared. All chemicals were sterilized separately by autoclaving $15 \mathrm{~min}$ at $121^{\circ} \mathrm{C}$.

A bacterial suspension of $10^{9}$ colony-forming units (CFU) $\mathrm{mL}^{-1}$ was prepared in sterile water and mixed with $3 \%$ sodium alginate in volume ratios $1: 1$, thereby producing $1.5 \%$ alginate containing bacteria in the amount $5 \times 10^{8}$ $\mathrm{CFU} \mathrm{mL} \mathrm{m}^{-1}$. The obtained mixture was stirred for $30 \mathrm{~min}$, then filled into a sterile syringe and dispensed dropwise with a needle $21 \mathrm{G}$ into a stirred solution of $0.2 \mathrm{M} \mathrm{CaCl}_{2}$, where formation of beads took place. The beads were allowed to solidify at room temperature for $60 \mathrm{~min}$.

Several types of alginate beads were prepared: with and without clay and/or glycerol, and with and without incubation of clay-containing beads in incubation medium with additives (Table 1). One portion of the beads was washed twice with sterile water, and the remainder was left in $\mathrm{CaCl}_{2}$ solution without washing. Wet beads were distributed in sterile glass tubes with screw caps, two grams in each and maintained at temperatures of 4 or $20^{\circ} \mathrm{C}$ for

Table 1.Treatments of incubation medium MHB with additives $[\mathrm{MHB}:$ additive $=1: 1(\mathrm{v} / \mathrm{v})]$ and storage conditions of claycontaining beads

\begin{tabular}{|lll|}
\hline No. & Additive & Storage conditions \\
\hline 1 & Distilled water & $2 \mathrm{~g}$ beads, $0.2 \mathrm{~mL} 0.2 \mathrm{M} \mathrm{CaCl}_{2}, 20^{\circ} \mathrm{C}$ \\
\hline 2 & Distilled water & $2 \mathrm{~g}$ beads, $0.2 \mathrm{~mL} 0.2 \mathrm{M} \mathrm{CaCl}_{2}, 4{ }^{\circ} \mathrm{C}$ \\
\hline 3 & Distilled water & $2 \mathrm{~g}$ beads, $0.2 \mathrm{~mL}$ distilled water, $20^{\circ} \mathrm{C}$ \\
\hline 4 & Distilled water & $2 \mathrm{~g}$ beads, $0.2 \mathrm{~mL}$ distilled water, $4{ }^{\circ} \mathrm{C}$ \\
\hline 5 & $0.2 \mathrm{M} \mathrm{CaCl}_{2}$ & $2 \mathrm{~g}$ beads, $0.2 \mathrm{~mL}$ distilled water, $20^{\circ} \mathrm{C}$ \\
\hline 6 & $0.2 \mathrm{M} \mathrm{CaCl}_{2}$ & $2 \mathrm{~g}$ beads, $0.2 \mathrm{~mL}$ distilled water, $4{ }^{\circ} \mathrm{C}$ \\
\hline
\end{tabular}


up to 74 days, but duration of one experiment was seven months. In part of the experiment, beads were incubated for an additional $24 \mathrm{~h}$ at room temperature in sterile Mueller Hinton Broth (MHB, Laboratorios Conda, Spain) containing acid casein peptone $17.5 \mathrm{~g} \mathrm{~L}^{-1}$, beef infusion 2.0 $\mathrm{g} \mathrm{L}^{-1}$ and corn starch $1.5 \mathrm{~g} \mathrm{~L}^{-1}$ and supplemented with yeast extract (Bio-Rad, France) $2.5 \mathrm{~g} \mathrm{~L}^{-1}$ with or without addition of $0.2 \mathrm{M} \mathrm{CaCl}_{2}$ (Table 1). After $24 \mathrm{~h}$, the liquid was decanted, and the beads were washed with sterile water, distributed in glass tubes as above and covered with distilled water or 0.2 $\mathrm{M} \mathrm{CaCl}_{2}$ for storage at 4 or $20^{\circ} \mathrm{C}$.

\section{Microbiological analyses}

Samples $(2 \mathrm{~g})$ of beads were ground in a sterile mortar with a pestle in a certain volume of sterile water to recover the bacteria. The number of bacterial CFU was determined by plating tenfold serial dilutions on Plate Count Agar (BioRad, France) plates using the spread plate method. Plates were incubated at $20^{\circ} \mathrm{C}$ for 7 days before counting colonies. Results were calculated and expressed as $\mathrm{CFU} \mathrm{g}{ }^{-1}$ of moist beads. Experiments were conducted in duplicate.

Viability of bacteria was analysed in slices of alginate beads using a LIVE/DEAD ${ }^{\star}$ BacLight $^{\text {tix }}$ Bacterial Viability Kit (Molecular Probes, USA) and fluorescence microscope (Leica DM 2000, Germany). Images were taken with camera Leica DFC 420 and processed by Image-Pro Express 6.0 (Media Cybernetics, USA) software.

\section{Statistical analysis}

Means, standard deviations and correlation coefficients were calculated. Analysis of variance (ANOVA) and the Student $t$-test was used to test differences among groups. Values of $p<0.05$ was considered statistically significant.

\section{Results}

\section{Characteristic of beads}

During the experiment bacteria containing alginate beads with and without clay additive were prepared. The mean diameter of beads was $2 \mathrm{~mm}$, but clay-containing beads had $16 \%$ greater weight and density than beads prepared without clay (Table 2). Beads with clay contained 53\% more bacterial CFU than the same size beads without clay. Visually, beads without clay were bright and before hardening almost transparent (Fig. 1A) while claycontaining beads were pale yellow (Fig. 1B). It was observed that clay additive reduced the edge smoothness (Fig. 1C-D). The LIVE/DEAD test demonstrated viability of all bacteria in both kinds of beads as well as even distribution of cells inside the bead (Fig. 2). Morphological changes were not observed during storage of beads.

\section{Survival of bacteria in alginate beads}

Bacteria remained alive in beads with and without clay additive during the experiment (74 days) at temperatures
Table 2. Characteristics of alginate beads containing bacteria

\begin{tabular}{|c|c|c|}
\hline Parameter & $\begin{array}{l}\text { Beads } \\
\text { without } \\
\text { clay }\end{array}$ & $\begin{array}{l}\text { Beads with } \\
\text { clay }\end{array}$ \\
\hline Number of beads in $2 \mathrm{~g}$ & 41 & 35 \\
\hline Mean bead diameter, $\mathrm{mm}$ & 2 & 2 \\
\hline Calculated weight of one bead, mg & 49 & 57 \\
\hline $\begin{array}{l}\text { Calculated volume of one bead, } \\
\mathrm{mm}^{3}\end{array}$ & 4.187 & 4.187 \\
\hline Calculated density, $\mathrm{g} \mathrm{cm}^{-3}$ & 11.67 & 13.57 \\
\hline $\begin{array}{l}\text { Calculated number of bacteria in } \\
\text { one bead after four days of storage, } \\
\text { CFU }\end{array}$ & $1.7 \times 10^{5}$ & $2.6 \times 10^{5}$ \\
\hline $\begin{array}{l}\text { Calculated number of bacteria in } \\
\text { one } g \text { of beads after four days of } \\
\text { storage, CFU }\end{array}$ & $3.5 \times 10^{6}$ & $4.6 \times 10^{6}$ \\
\hline
\end{tabular}

of 4 and $20^{\circ} \mathrm{C}$ (Fig. 3). After 74 days of storage, the number of CFU g ${ }^{-1}$ increased by 1.1 to $1.3(p<0.05)$ and 0.1 to $0.2 \log (p>0.05)$ in the case of alginate beads with and without clay, respectively, in comparison with the initial concentration regardless of the storage temperature.

The immobilized bacterial association consisted of seven species and it was possible to distinguish colonies of one of these species, i.e. Burkholderia cepacia. This species formed smooth round colonies with a fluorescent greenish-yellow colour in the Plate Count Agar. Decrease of the proportion of $B$. cepacia was observed during storage, especially in clay-containing beads, but data were not obtained in this experiment.

Fluctuations in the number of $\mathrm{CFU}$ in the range of 1.8 $\log \mathrm{CFU} \mathrm{g^{-1 }}$ at the beginning (day 0) of the experiment, exceeding the limits of possible errors, were observed in beads with and without clay and glycerol (Fig. 4). The number of CFU tended to increase during the first two weeks $(p>0.05)$, but significantly decreased on day 27 . Then, the number of colonies increased and at the end of the experiment (203 days) did not significantly differ from the number at the beginning, thereby indicating good survival of bacteria.

The number of CFU increased by 0.47 to $0.57 \log$ after day-long incubation in nutrient medium of clay-containing beads, which was followed by a reduction. Fluctuations in the range of $3 \log \mathrm{CFU} \mathrm{g}{ }^{-1}$ were observed in tests carried out in the first 22-day period in all three treatments especially when beads were stored at temperature $4{ }^{\circ} \mathrm{C}$ (Fig. 5). The lowest number of colonies was after 8 days of storage in treatments 1 to 4 (incubation in MHB with water) and after 11 days of storage in treatments 5 and 6 (incubation in MHB with $\mathrm{CaCl}_{2}$ solution), regardless of storage medium. Treatments 4 and 6 had the largest number of colonies at the end of the experiment after 183 days, i.e. $7.7 \mathrm{log}$ $\mathrm{CFU} \mathrm{g}{ }^{-1}$. Number of colonies was 2.3 (treatment 4) and 

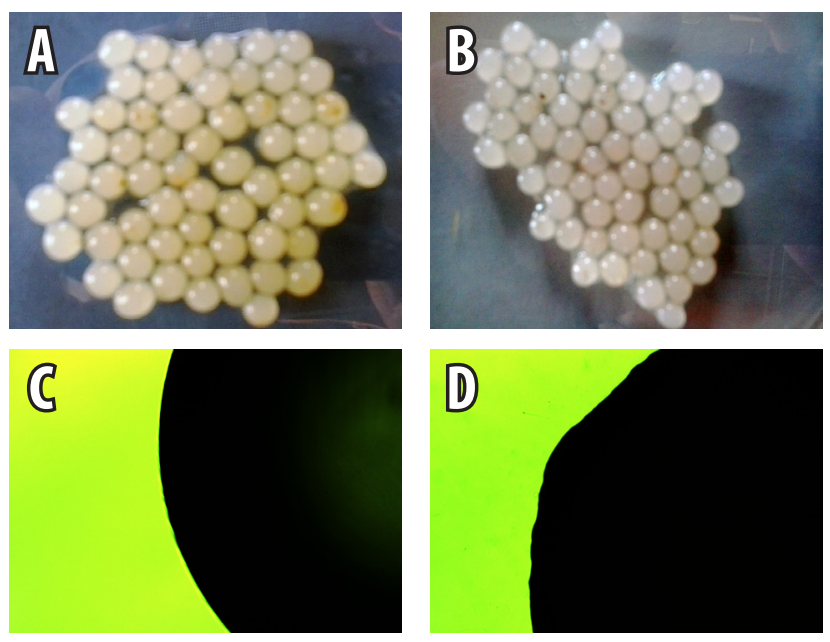

Fig. 1. Alginate beads $2 \mathrm{~mm}$ in diameter without clay $(B, C)$ and with clay $(A, D)$. C and D, shape of bead edges under magnification of $100 \times$.

1.9 (treatment 6) times more than in the corresponding treatments that were stored at $20^{\circ} \mathrm{C}$. Beads of treatments 1 and 2 had the smallest amount of CFU. The number of bacterial CFU $\mathrm{g}^{-1}$ did not significantly differ from the number at the beginning in treatments $1,2,3$ and 5 , but were 4.0 to 4.4 times higher $(p<0.05)$ than at the beginning in treatments 4 and 6 .

\section{Discussion}

In this study, a bacterial association was successfully immobilized in alginate beads that were $2 \mathrm{~mm}$ in diameter. All tested treatments, with or without clay or glycerol, with or without incubation in nutrient medium or $\mathrm{CaCl}_{2}$ solution, showed good results in terms of survival of bacteria immediately after entrapment in gel and during at least six months storage of beads at temperature $4{ }^{\circ} \mathrm{C}$ and $20^{\circ} \mathrm{C}$. The number of bacterial CFU increased by 1.1 to $1.3 \log \mathrm{g}^{-1}$ in clay-containing beads during the experiment regardless of storage temperature (Fig. 3) but it remained at baseline levels in other treatments. Power et al. (2011)

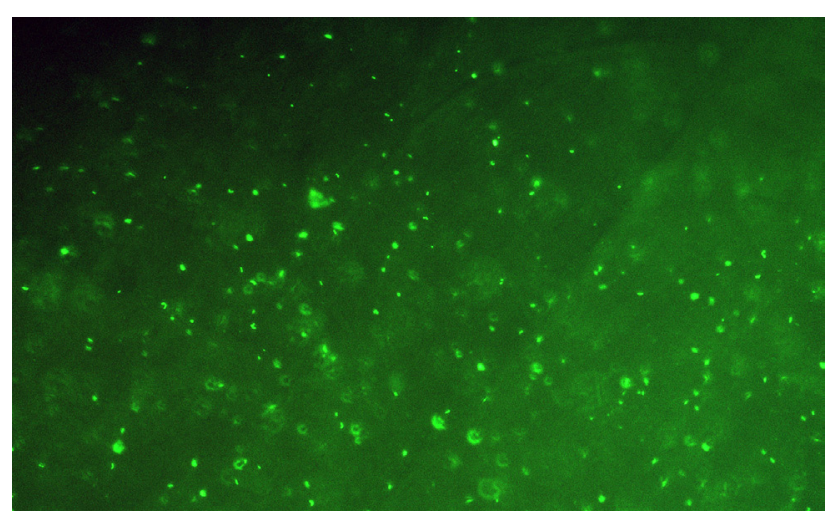

Fig. 2. Distribution of live (green) bacteria inside the alginate bead (LIVE/DEAD test). also showed $100 \%$ recovery of viable Pseudomonas fluorescens F113 after 250 days of storage in alginate beads under ambient temperature and concluded that alginate beads are an effective storage system for polychlorinated biphenyls degrading inocula. Like us, they also observed a reduction of the number of $\mathrm{CFU}$, which occured 40 days after preparation of beads, and later the population began to increase.

Five percent clay addition resulted in reduced smoothness of bead edges, probably because a portion of the clay particles protruded outward. It has been demonstrated that also the addition of attapulgite (magnesium aluminium phyllosilicate) in the amount of 0.5 to $1 \%$ and calcium carbonate in the amount of 3 to $7 \%$ changed the roughness and resulted in unevenly shaped alginate granules (Wang et al. 2014).

Trevors et al. (1993) amended alginate with TY medium (ingredients: tryptone $10 \mathrm{~g} \mathrm{~L}^{-1}$, yeast extract $5 \mathrm{~g} \mathrm{~L}^{-1}$ and $\mathrm{NaCl} 10 \mathrm{~g} \mathrm{~L}^{-1}$ ) or soil extract and concluded that there was a negligible effect on long-term survival of $P$. fluorescens Rsf cells. However, amendment with skim milk or with skim milk plus bentonite clay significantly promoted survival of the cells. In our study, addition of $10 \%$ glycerol did not have significant impact on the survival of bacteria. Nassif et al. (2002) added glycerol to a suspension of E. coli to $10 \%$ final concentration before entrapment in silica gel. After one month, the percentage of culturable bacteria remained 30\% higher than in silica gels without glycerol. Some authors have described additional incubation of bacteria-containing prepared alginate beads in nutrient broth for 24 to $48 \mathrm{~h}$ (Bashan 1986), so that bacteria could multiply inside the beads. In our study, this approach did not give any additional benefit in any of the six treatments of incubation and storage media, and storage temperature and the number of bacterial CFU remained at the initial level (Fig. 5).

To the best of our knowledge, this study is one of a few conducted on immobilization of a natural bacterial association instead of immobilization of individual species or an artificial microbial consortium. For example, ElKomy (2005) co-immobilized Azospirillum lipoferum and Bacillus megaterium in alginate beads to improve phosphorus solubilization. Huang and Yang (1998) coimmobilized homolactic and homoacetic bacteria in a fibrous-bed bioreactor for acetate production from whey lactose. A mixed culture of bacterium Zymomonas mobilis and yeast Saccharomyces cerevisiae was immobilized to improve fermentation performance for ethanol production (De Almeida, de Angelis 2016). Bergero et al. (2017) used immobilization of a consortium of Aeromonas hydrophila and Pseudomonas putida in Ca-alginate beads to achieve degradation of cationic surfactants. Problems with multi-strain associations or consortia arise due to different requirements and response of individual strains. For example, all fungi [Gliocladium virens (currently 
Trichoderma virens), Penicillium oxalicum, Talaromyces flavus and Trichoderma viride], but not Pseudomonas cepacia (currently Burkholderia cepacia), were viable after pellet formation in $\mathrm{CaCl}_{2}$ (Fravel et al. 1985). In our study, decrease of the proportion of $B$. cepacia was observed during the storage of alginate beads. At the same time, the total number of bacteria increased (Fig. 3). This means that populations of one or several bacterial strains grew which

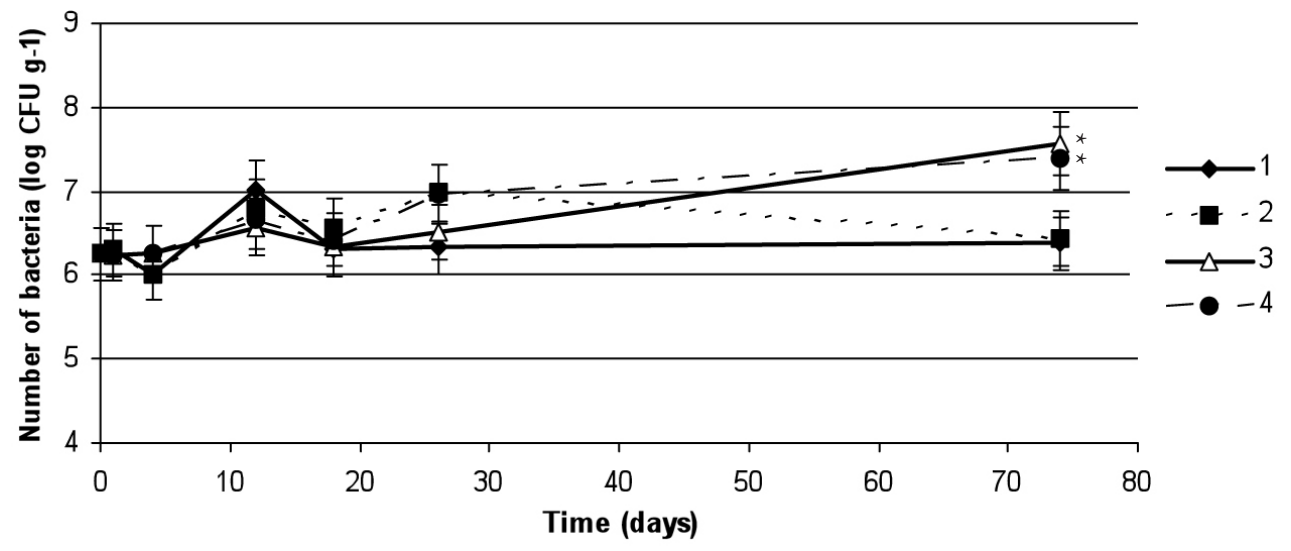

Fig. 3. Survival of bacteria in alginate beads with or without clay during storage at temperature of 4 and $20^{\circ} \mathrm{C}$. 1 , without clay, $4{ }^{\circ} \mathrm{C}$; 2 , without clay, $20^{\circ} \mathrm{C}$; 3 , with clay, $4^{\circ} \mathrm{C}$; 4 , with clay, $20^{\circ} \mathrm{C}$. Values are mean $\pm \mathrm{SD}$ of two replicates. ${ }^{*}$, significant difference from the day 0 .

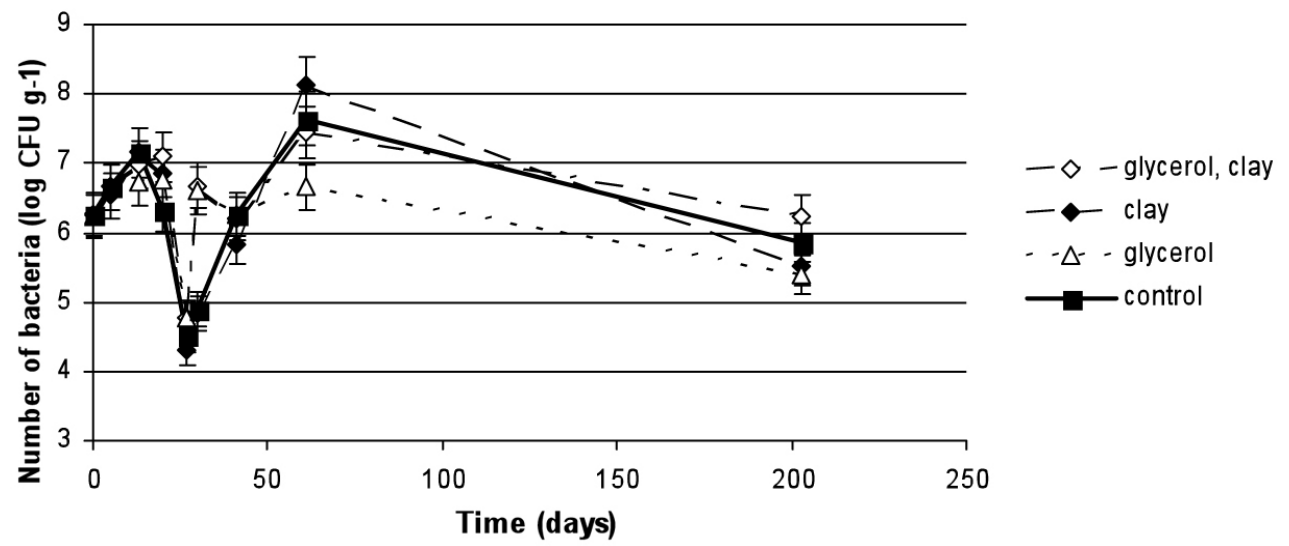

Fig. 4. Effect of clay and glycerol addition in beads on viability of bacteria during storage at $4{ }^{\circ} \mathrm{C}$. Values are mean $\pm \mathrm{SD}$ of two replicates.

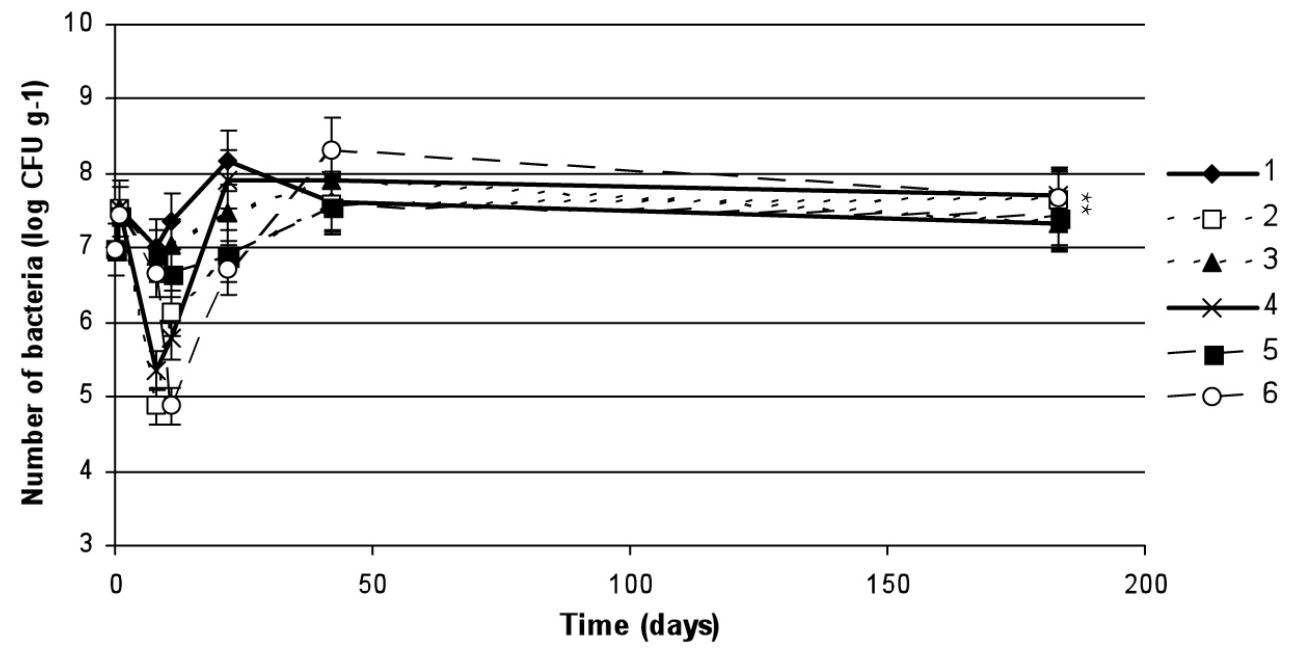

Fig. 5. Effect of incubation conditions of clay-containing beads on viability of bacteria. Treatments (Table 1 ) 1 to 4 were incubated in MHB with added water but treatments 5 and 6 were incubated in $\mathrm{MHB}$ with $\mathrm{CaCl}_{2}$ solution. After incubation, the beads were stored in $\mathrm{CaCl}_{2}$ solution in treatments 1 and 2 but in water in the other treatments. Treatments 1,3 and 5 were stored at $20^{\circ} \mathrm{C}$. Treatments 2,4 and 6 were stored at $4^{\circ} \mathrm{C}$. Values are mean \pm SD of two replicates. ${ }^{*}$, significant difference with the day 0 . 
in turn led to the changes in strain proportions. This may affect not only composition but also metabolic activity of the multi-strain association.

The investigated association consisted of seven bacterial strains naturally adapted to acid tar-contaminated soil and, therefore, suitable for bioremediation applications (unpublished data) in the presence of toxic substances. Attempts were made to improve the survival of the association through immobilization in alginate gel to make it more resistant to different kinds of pollution. Further studies are necessary to evaluate bioremediation activities of immobilized associations in laboratory and field conditions and molecular approaches are needed to investigate fate of individual components.

\section{Acknowledgements}

This study was supported by the National Research Programme of Latvia "Sustainable Use of Forests and Mineral Deposits New Products and Technologies (ResProd)". The authors are very grateful to Livija Vulfa for the isolation and investigation of bacterial association.

\section{References}

Abed R.M.M., Al-Sabahi J., Al-Maqrashi F., Al-Habsi A., Al-Hinai M. 2014. Characterization of hydrocarbon-degrading bacteria isolated from oil-contaminated sediments in the Sultanate of Oman and evaluation of bioaugmentation and biostimulation approaches in microcosm experiments. Int. Biodeter. Biodegr. 89: 58-66.

Barreca S., Orecchio S., Pace A. 2014. The effect of montmorillonite clay in alginate gel beads for polychlorinated biphenyl adsorption: isothermal and kinetic studies. Appl. Clay Sci. 99: 220-228.

Bashan Y. 1986. Alginate beads as synthetic inoculant carriers for slow release of bacteria that affect plant growth. Appl. Environ. Microbiol. 51: 1089-1098.

Bento F.M., Camargo F.A.O., Okeke B.C., Frankenberger W.T. 2005. Comparative bioremediation of soils contaminated with diesel oil by natural attenuation, biostimulation and bioaugmentation. Bioresour. Technol. 96: 1049-1055.

Bergero M.F., Liffourrena A.S., Opizzo B.A., Fochesatto A.S., Lucchesi G.I. 2017. Immobilization of a microbial consortium on Ca-alginate enhances degradation of cationic surfactants in flasks and bioreactor. Int. Biodeter. Biodegr. 117: 39-44.

Cassidy M.B., Lee H., Trevors J.T. 1996. Environmental applications of immobilized microbial cells: a review. J. Ind. Microbiol. Biotechnol. 16: 79-101.

Crisafi F., Genovese M., Smedile F., Russo D., Catalfamo M., Yakimov M., Giuliano L., Denaro R. 2016. Bioremediation technologies for polluted seawater sampled after an oil-spill in Taranto Gulf (Italy): a comparison of biostimulation, bioaugmentation and use of a washing agent in microcosm studies. Mar. Pollut. Bull. 106: 119-126.

De Almeida N.C., de Angelis D.F. 2016. Immobilization and association of microorganisms to improve fermentation performance for ethanol production. J. Agric. Biotech. Sustain. Dev. 8: 7-15.
Dercova K., Sejakova Z., Skokanova M., Barancikova G., Makovnikova J. 2007. Bioremediation of soil contaminated with pentachlorophenol (PCP) using humic acids bound on zeolite. Chemosphere 66: 783-790.

El-Komy H.M.A. 2005. Coimmobilization of A. lipoferum and B. megaterium for plant nutrition. Food Technol. Biotechnol. 43: 19-27.

Ely A., Baudu M., Kankou M.O.S.A.O., Basly J.P. 2011. Copper and nitrophenol removal by low cost alginate/ Mauritanian clay composite beads. Chem. Eng. J. 178: 168-174.

Fravel D.R., Marois J.J., Lumsden R.D., Connick W.J.Jr. 1985. Encapsulation of potential biocontrol agents in an alginateclay matrix. Phytopathology 75: 774-777.

Gupta A., Kaushik C.P., Kaushik A. 2000. Degradation of hexachlorocyclohexane $(\mathrm{HCH} ; \alpha, \beta, \gamma$ and $\delta)$ by Bacillus circulans and Bacillus brevis isolated from soil contaminated with HCH. Soil Biol. Biochem. 32: 1803-1805.

Hassanshahian M., Emtiazi G., Caruso G., Cappello S. 2014. Bioremediation (bioaugmentation/ biostimulation) trials of oil polluted seawater: a mesocosm simulation study. Mar. Environ. Res. 95: 28-38.

Huang Y., Yang S.T. 1998. Acetate production from whey lactose using coimmobilized cells of homolactic and homoacetic bacteria in a fibrous-bed bioreactor. Biotechnol. Bioeng. 60: 498-507.

Karel S.F., Libicki S.B., Robertson C.R. 1985. The immobilization of whole cells: engineering principles. Chem. Eng. Sci. 40: 1321-1354.

Kim D.E., Lee E.Y., Kim H.S. 2009. Cloning and characterization of alginate lyase from a marine bacterium Streptomyces sp. ALG-5. Mar. Biotechnol. 11: 10-16.

Kim M.K., Singleton I., Yin C.R., Quan Z.X., Lee M., Lee S.T. 2006. Influence of phenol on the biodegradation of pyridine by freely suspended and immobilized Pseudomonas putida MK1. Lett. Appl. Microbiol. 42: 495-500.

Kitamikado M., Yamaguchi K., Tseng C.H., Okabe B. 1990. Method designed to detect alginate-degrading bacteria. Appl. Environ. Microbiol. 56: 2939-2940.

Kundu D., Hazra C., Chaudhari A. 2016. Bioremediation potential of Rhodococcus pyridinivorans NT2 in nitrotoluenecontaminated soils: the effectiveness of natural attenuation, biostimulation and bioaugmentation approaches. Soil Sediment Contam. 25: 637-651.

Lebeau T. 2011. Bioaugmentation for in situ soil remediation: how to ensure the success of such a process. In: Singh A., Parmar N., Kuhad R.C. (eds) Bioaugmentation, Biostimulation and Biocontrol. Springer, Berlin, Heidelberg, pp. 129-186.

Lee K.Y., Mooney D.J. 2012. Alginate: properties and biomedical applications. Prog. Polym. Sci. 37: 106-126.

Lewis J.A., Papavizas G.C. 1985. Characteristics of alginate pellets formulated with Trichoderma and Gliocladium and their effect on the proliferation of the fungi in soil. Plant Pathol. 34: 571577.

Li H., Hua T., Zhang Y., Xiong X., Gong Z. 2005. Bioremediation of contaminated surface water by immobilized Micrococcus roseus. Environ. Technol. 26: 931-939.

Luckarift H.R., Sizemore S.R., Farrington K.E., Fulmer P.A., Biffinger J.C., Nadeau L.J., Johnson G.R. 2011. Biodegradation of medium chain hydrocarbons by Acinetobacter venetianus 2AW immobilized to hair-based adsorbent mats. Biotechnol. Progr. 27: 1580-1587. 
Matsumura Y., Akahira-Moriya A., Sasaki-Mori M. 2015. Bioremediation of bisphenol-A polluted soil by Sphingomonas bisphenolicum $\mathrm{AO} 1$ and the microbial community existing in the soil. Biocontrol Sci. 20: 35-42.

McCarty P.L., Criddle C.S. 2012. Chemical and biological processes: the need for mixing. In: Kitanidis P.K., McCarty P.L. (eds) Delivery and Mixing in the Subsurface: Processes and Design Principles for In Situ Remediation. Springer, New York, Heidelberg, Dordrecht, London, pp. 7-52.

Mohanty G., Mukherji S. 2008. Biodegradation rate of diesel range n-alkanes by bacterial cultures Exiguobacterium aurantiacum and Burkholderia cepacia. Int. Biodeter. Biodegr. 61: 240-250.

Mørch Y.A., Donati I., Strand B.L., Skjåk-Braek G. 2006. Effect of $\mathrm{Ca}^{2+}, \mathrm{Ba}^{2+}$, and $\mathrm{Sr}^{2+}$ on alginate microbeads. Biomacromolecules 7: 1471-1480.

Mrozik A., Piotrowska-Seget Z. 2010. Bioaugmentation as a strategy for cleaning up of soils contaminated with aromatic compounds. Microbiol. Res. 165: 363-375.

Nassif N., Bouvet O., Rager M.N., Roux C., Coradin T., Livage J. 2002. Living bacteria in silica gels. Nat. Mater. 1: 42-44.

Power B., Liu X., Germaine K.J., Ryan D., Brazil D., Dowling D.N. 2011. Alginate beads as a storage, delivery and containment system for genetically modified PCB degrader and PCB biosensor derivatives of Pseudomonas fluorescens F113.J. Appl. Microbiol. 110: 1351-1358.

Pradeep V., Subbaiah U.M. 2016. Use of Ca-alginate immobilized Pseudomonas aeruginosa for repeated batch and continuous degradation of Endosulfan. 3 Biotech 6: 124. doi:10.1007/ s13205-016-0438-2

Shawky H. A. 2011. Improvement of water quality using alginate/ montmorillonite composite beads. J. Appl. Polym. Sci. 119: 2371-2378.

Simarro R., Gonzalez N., Bautista L.F., Molina M.C. 2013. Biodegradation of high-molecular-weight polycyclic aromatic hydrocarbons by a wood-degrading consortium at low temperatures. FEMS Microbiol. Ecol. 83: 438-449.

Smidsrød O. 1974. Molecular basis for some physical properties of alginates in the gel state. Faraday Discuss. Chem. Soc. 57: 263-274.

Szulc A., Ambrozewicz D., Sydow M., Ławniczak Ł., PiotrowskaCyplik A., Marecik R., Chrzanowski Ł. 2014. The influence of bioaugmentation and biosurfactant addition on bioremediation efficiency of diesel-oil contaminated soil: feasibility during field studies. J. Environ. Manage. 132: 121128.

Tang J.-C., Taniguchi H., Chu H., Zhou Q., Nagata S. 2009. Isolation and characterization of alginate-degrading bacteria for disposal of seaweed wastes. Lett. Appl. Microbiol. 48: 38-43.

Trevors J.T., Van Elsas J.D., Lee H., Wolters A.C. 1993. Survival of alginate encapsulated Pseudomonas fluorescens cells in soil. Appl. Microbiol. Biotechnol. 39: 637-643.

Trivedi P., Pandey A., Palni L.M.S. 2005. Carrier-based preparations of plant growth-promoting bacterial inoculants suitable for use in cooler regions. World J. Microbiol. Biotechnol. 21: 19-23.

Wang H.W., Hua F., Zhao Y.C., Wang X. 2014. Immobilization of Pseudomonas sp. DG17 onto sodium alginate-attapulgitecalcium carbonate. Biotechnol. Biotechnol. Equip. 28: 834-842.

Weir S.C., Dupuis S.P., Providenti M.A., Lee H., Trevors J.T. 1995. Nutrient-enhanced survival of and phenanthrene mineralization by alginate-encapsulated and free Pseudomonas sp. UG14Lr cells in creosote-contaminated soil slurries. Appl. Microbiol. Biotechnol. 43: 946-951.

Willaert R., Baron G. 1996. Gel entrapment and microencapsulation: methods, applications and engineering principles. Rev. Chem. Eng. 12: 5-205.

Zohar-Perez C., Ritte E., Chemin L., Chet I., Nussinovitch A. 2002. Preservation of chitinolytic Pantoea agglomerans in a viable form by cellular dried alginate-based carriers. Biotechnol. Prog. 18: 1133-1140. 